\title{
28 Research Square \\ Factors Controlling the Extreme Storm Surge \\ Flooding - Insights From Coastal Sedimentary Record of the Southern Baltic Sea
}

Karolina Leszczyńska ( $\nabla$ karles3@amu.edu.pl )

Adam Mickiewicz University in Poznań

Karl Stattegger

Adam Mickiewicz University in Poznań

Damian Moskalewicz

University of Gdańsk

Robert Jagodziński

Adam Mickiewicz University in Poznań

Mikołaj Kokociński

Adam Mickiewicz University in Poznań

Przemysław Niedzielski

Adam Mickiewicz University in Poznań

Witold Szczuciński

Adam Mickiewicz University in Poznań

\section{Research Article}

Keywords: extreme storm, surge flooding, coastal, sedimentary

Posted Date: January 3rd, 2022

DOI: https://doi.org/10.21203/rs.3.rs-1217227/v1

License: (9) (i) This work is licensed under a Creative Commons Attribution 4.0 International License.

Read Full License 


\section{Abstract}

Climate change and related sea-level rise pose significant threats to sandy lowland coasts, which account for approximately $30 \%$ of the global coastline. However, the role of key controlling factors responsible for the frequency and extent of extreme storm surge of inundation regime is not yet fully understood. Here, we present the longest to date, high-resolution sedimentary record of extreme storm surge flooding from the microtidal southern Baltic Sea, spanning two periods: 3.6-2.9 ka BP and 0.7 ka BP until present. Wetland sediments, including sandy event layers, were analyzed by sedimentological (grain size, loss-onignition, micromorphology), geochronological $\left({ }^{14} \mathrm{C},{ }^{210} \mathrm{~Pb},{ }^{137} \mathrm{Cs}\right)$, geochemical (XRF), mineralogical (heavy minerals) and micropaleontological (diatoms) methods. Our results revealed that both periods are characterized by high-frequency storm surge flooding in order of $1.3-4.2$ events per century. They are correlated to widely recognized enhanced storminess periods in NW Europe and took place during both rising and fluctuating sea levels. The presented results show that the storm surge driven coastal inundation frequency and extent largely depend on the development of coastal barriers (e.g., beach ridges). Thus, in the context of the future coastal storm surge hazard, the protection of existing coastal barriers is essential.

\section{Introduction}

Sandy coasts and adjacent lowlands of high socioeconomic value associated with industry, tourism and ecology occupy more than $30 \%$ of the global coastline (1). Threats by ongoing climate change and rising sea level along with regionally enhanced frequency and intensity of storms (2) are predicted by all future greenhouses gases emission scenarios (3-5). Consequently, sandy lowland coasts face and will continue to face a period of instability and more frequent storm flooding (6). Hypotheses on future coastal instability range from catastrophic loss of sandy beaches with rising sea level by the end of the century to the important role sedimentary processes to maintain a relatively stable coastal morphology and ecosystems under moderate rates of sea-level rise (7). What is commonly accepted is the fact that unstable climatic conditions and sea-level change result in rising uncertainty in predicting the occurrence of devastating coastal flooding $(4,8)$.

Extreme storm water level causing storm surge flooding is associated with a rapid rise in the water level due to the influence of wind, waves and atmospheric pressure on the sea surface, combined with tides (9). The storm surges on the coastline may be classified to 4 types of regimes: swash, collision, overwash and inundation (9). Catastrophic storm surge flooding is mainly associated with inundation regime, i.e. the case when the storm surge overtops the beach barrier and floods the area behind on a large distance. The susceptibility of a given coast to storm surge flooding may change due to many factors, among which are sea-level rise and coastal landform development as well as storminess, defined in terms of the number of days with strong winds of 7 or more Beaufort scale (2). However, knowledge of the role of these controlling components is limited and can be assessed only if other factors, such as tides, bathymetry, and wave fetch length, are comparable between study sites or have not changed with time. 
As the historical observations and written sources span only a short period of the storm flooding history anywhere, it is important to go back in time beyond the instrumental record and to analyze sedimentary archives (10). Moreover, comparison to historical times shows that recent, instrumentally recorded, storms may not be an adequate reference to worst case scenarios; it is the sedimentary archive that may provide record long enough to capture the high magnitude and low probability events (11).

The dawn of the study of storm deposit records (palaeotempestology) dates back to the 1960s $(12,13)$, and there are some inspiring palaeotempestological works done on the American and European coasts of the Atlantic Ocean (14-16). Limited palaeotempestological research is also available for the Baltic Sea area, where several catastrophic storm surges in the coastal sedimentary archives for the past 2000 years were documented $(11,17)$, extending the tide gauge record from Świnoujście in the southern Baltic Sea, one of the longest tide-gauge records in the world, covering more than 200 years $(11,18)$.

The Baltic Sea is a European marginal sea connected to the North Atlantic ocean. It is exceptionally valuable target to investigate palaeostorms, as it is nontidal/microtidal sea which offers widespread coastal lowlands in particular at its southern coast in Poland and Germany. Here the storm flooding signal is not biased by tidal effects and water level fluctuations are almost exclusively related to storm surges $(11,17,19)$ and well-documented past sea-level changes. The Baltic area, characterized by transitional oceanic-continental temperate climate is highly sensitive to latitudinal shifts in North Atlantic Oscillation (NAO) and following from that, changes of the westerly storm tracks (20). Recently, the southern Baltic coast has been identified as a "hot spot", where the rate of storm surge flooding overtopping coastal barriers is one of the highest in the world during recent decades and is expected to increase in the future (21).

The present paper documents sedimentary succession from the Polish coastal wetland located at Mechelinki, Puck Bay within the Gulf of Gdańsk (Fig. 1). The deposits of the last 7.5 ka BP include the high-resolution records of extreme storm surge of inundation regime within two periods: from approximately 3.6 to $2.9 \mathrm{ka}$ BP and from approximately $0.7 \mathrm{ka}$ BP until present. The advantage of this study lies within the fact that we could reconstruct the past storm induced coastal flooding and put it into context of costal evolution and associated with well-documented sea-level changes at the same coastal setting, unaffected by anthropogenic activity. Our research evaluates the susceptibility of the area to flooding as dependent on the development of coastal landforms at various sea-level stages. We address the question of what are the factors controlling the susceptibility of the coast to storm surge flooding: is it enhanced storminess, sea-level change trend, or coastal landform development.

\section{Regional setting}

The Mechelinki wetland is located on the coast of Puck Bay within the Gulf of Gdańsk, southern Baltic Sea, in Poland (Fig. 1). It represents an extensive lowland coast, which developed after the decay of the Scandinavian ice sheet and during the emergence of the Baltic Sea. Holocene wetland sediments, including sandy intercalations, are underlain by Pleistocene glacio-fluvial and fluvial gravels and sands 
(22). The modern net vertical crustal movements are close to zero (23). The Gulf of Gdańsk, together with Puck Bay, was affected by marine transgression for the first time at approximately $6.2 \mathrm{ka}$ BP, during the last phase of rapid Littorina marine transgression, as recorded in lagoonal deposits found at $-5.15 \mathrm{~m}$ below mean sea level (bmsl) (24-26). The initial high rates of sea-level rise of $3.6 \mathrm{~mm} /$ year, decelerated after $5.5 \mathrm{ka}$ BP to average rates of $0.4 \mathrm{~mm} /$ year from $4.5 \mathrm{ka}$ BP until the Little Ice Age (LIA). Sea level was stable or slightly dropped during the LIA $(0.4-0.14 \mathrm{ka} \mathrm{BP})$ and rose again during the past 140 years at a rate of $1.0 \mathrm{~mm}$ /year until $1960 \mathrm{CE}$, as recorded from Świnoujście, when it accelerated to $2.4 \mathrm{~mm} /$ year (18) in Gdańsk and $2.0 \mathrm{~mm} /$ year in Władysławowo (18). Alternatively, Uścinowicz (25) suggested a stepwise rise of sea level during the last 2000 years with two periods of 40 to $50 \mathrm{~cm}$ sea-level rise from 1.75 to 1.3 and 0.8 to $0.5 \mathrm{ka}$ BP respectively with sea-level rise rates up to $2.3 \mathrm{~mm} /$ year.

The shallow Puck Bay is the northwestern most extension of the Gulf of Gdańsk (Fig. 1), which is separated from the open sea by 150-3000 m wide spit (Hel Peninsula) covered with up to few meters high dunes. The average water salinity is approximately 7.3 PSU (27). The research site at Mechelinki wetland is separated from the bay by a $15-20 \mathrm{~m}$ wide subaerial part of the beach with a slope of up to $10^{\circ}$ followed by a 20-25 m wide beach ridge and initial foredune up to $2 \mathrm{~m}$ above mean sea level (amsl) high. Recent small washover fans can be observed near the foredune crest at Mechelinki (Fig. 1). Offshore, the seafloor is gently deepening, reaching a water depth of $10 \mathrm{~m}$ around $3 \mathrm{~km}$ from the shore.

Shallow waters in Puck Bay cause lower, but more prolonged rise of the sea-level during storm conditions compared to the open, tidal seas. The mean decadal number of storm surge conditions understood as water level exceeding $70 \mathrm{~cm}$ amsl $(28,29)$, at various parts of the coast of Puck Bay and Gulf of Gdańsk, from 1960 to 2010 varied between 156 and 253 events in Hel and Gdańsk mareographic stations, respectively (28). The theoretical 100-year maximum storm surge water level of 160 to $180 \mathrm{~cm}$ amsl is similar to the maximum measured sea level at the Gdańsk gauge station of $144 \mathrm{~cm}$ amsl during a storm in November 2004 (29). However, this storm surge did not cause extensive coastal flooding or leave recognizable sedimentary records in coastal wetlands (11).

The majority of storm-weather conditions occur in the autumn and winter. A low-pressure anomaly in the in the north, over Iceland, and a high pressure anomaly in the south over Azores, creates a steep pressure gradient enhancing the strength of westerlies influencing the Baltic Sea region (20). This situation is strengthened during positive NAO phases. The combination of conditions of water set-up by persistent westerlies at the eastern Baltic coast and turning wind directions to northerly and easterly winds creates favorable conditions for extreme storm surge flooding in the Gulf of Gdańsk and Puck Bay. Those north to east winds account for approximately $25 \%$ of total wind directions.

The northerly wind speed of $15 \mathrm{~m} / \mathrm{s}$ causes a wave height of approximately $0.2 \mathrm{~m}$ and easterly winds of up to $0.4 \mathrm{~m}$ (30). North Atlantic storminess is defined in terms of the number of days with strong winds above $13.9 \mathrm{~m} / \mathrm{s}$, what is wind strength 7 in Beaufort scale, for one or more measurement during a 6 hours period over the course of any single day (31). At Gulf of Gdańsk very strong winds above $15 \mathrm{~m} / \mathrm{s}$ occur for 6 days/year on average and result in moderate waves. 


\section{Results}

\section{Sedimentary archive}

The documented sedimentary succession at Mechelinki (Fig. 1) comprises approximately $4.5 \mathrm{~m}$ of wetland sediments intercalated with multiple, easily distinguishable, sand layers a few centimeters thick (Fig. 2). The lateral extent of the sand layers was documented within four geological transects perpendicular to the coast (Fig. 1). Within all the transects, the sand layers thin landwards. The layers below a depth of $100 \mathrm{~cm}$ pinch out closer to the coastline (between 60 and $160 \mathrm{~m}$ ) than the upper layers (reaching between 140 and 320 m landwards).

A detailed description of the sediment succession at Mechelinki is based on master core M12 (Fig. 2). The basal unit is composed of gyttja deposits (450-415 cm sediment depth). They are composed of well-sorted, unimodal, fine-grained sand of pale yellow color, which changes into massive, compacted, mottled gray and blue, fine-grained sand with admixture of silt (Fig. 2). Above the gyttja, there is peaty sand with variable admixtures of organic matter at various stages of decomposition. These deposits were subjected to further detailed investigation. The admixture of organic matter varies, with a maximum of $60 \%$. These wetland deposits are intercalated with at least 24 sand layers up to $10 \mathrm{~cm}$ thick (Fig. 2).

To interpret the origin of sand layers and reconstruct wetland environments, the deposits were dated and characterized through loss-on-ignition, grain size (Figs. 2, 3, Supplementary Table 1, 2), geochemical (Fig. 3, Supplementary Table 3) and micromorphological analyses (Supplementary Table 4, Supplementary Fig. 1) with diatom and heavy mineral analyses used as supplementary methods (Supplementary Tables 5,6). Moreover, several end member samples from the beach and dune were analyzed in the same way.

All sand layers comprise $>90 \%$ mineral matter (dry mass). The wetland deposits do not contain more than $80 \%$ of mineral matter, except for core sections sandwiched between event sand layers. The grain-size distribution of sand layers is unimodal, and the mean grain size is coarse sand (Fig. 2). When analyzed at the microscale (thin sections), the sand layers display clast-supported texture and inclined stratification (Supplementary Table 4, Supplementary Fig. 1). The lower contact is sharp and undulating. Clasts of underlying peaty deposits are incorporated into the overlying sand layers, as rip-up clasts and as clusters of dispersed organic matter mixed with sand.

Geochemical analysis included major and trace elements, e.g., $\mathrm{Mg}, \mathrm{Ca}, \mathrm{Na}, \mathrm{K}$, and $\mathrm{Rb}$, which are considered to be indicators of marine origin (Fig. 3, Supplementary Table 3). The core sections with sand layers are enriched in $\mathrm{Na}, \mathrm{K}$ and $\mathrm{Rb}$. Among wetland deposits, the elements that prevail are $\mathrm{Mn}, \mathrm{Fe}$ and $\mathrm{S}$. In samples from the uppermost section of the core, there are significant amounts of $\mathrm{Zn}$ and As, which is likely evidence of anthropogenic pollution.

Diatoms in selected sand layers and nearby wetland deposits generally revealed similar assemblages (Supplementary Table 5). The majority of benthic taxa represent fresh/brackish to freshwater species, 
including diatoms of wide ecological tolerance. The heavy mineral assemblage of the sand layers is dominated by amphiboles, garnets and epidotes with accessory amounts of other groups

(Supplementary Table 6). In comparison to the reference dune sample, sand deposits within the core have higher amounts of amphiboles and epidotes and lower amounts of garnets.

\section{Age control}

The calibrated ${ }^{14} \mathrm{C}$ dates of samples taken from master core M12 generally revealed an increase in age with depth, except for four samples excluded from the age-depth modeling (Supplementary Table 7, 8). The composed age-depth model (Figs. 2, 4, Supplementary Fig. 2) revealed three sections of relatively steady accumulation: 0-156 cm (accumulated since approximately $0.7 \mathrm{ka}$ cal yrs BP to present at a rate of $\sim 0.21 \mathrm{~cm} / \mathrm{yr}$ ), $185-285 \mathrm{~cm}$ (accumulated between approximately 3.6 and 2.9 ka cal yrs BP at a rate of $\sim 0.14 \mathrm{~cm} / \mathrm{yr}$ ), and 298-410 cm (accumulated between approximately 7.5 and $5.4 \mathrm{ka}$ cal yrs BP at a rate of $\sim 0.05 \mathrm{~cm} / \mathrm{yr}$ ). These sections are separated by two intervals, $156-185 \mathrm{~cm}$ and $285-298 \mathrm{~cm}$, with much lower average accumulation rates, on the order of 0.02 and $0.007 \mathrm{~cm} / \mathrm{yr}$, respectively. The latter interval is likely associated with erosion event(s).

The activity profiles of ${ }^{210} \mathrm{~Pb}_{\mathrm{ex}}$ and ${ }^{137} \mathrm{Cs}$ (Supplementary Fig. 3) were constructed from samples taken from a twin core extracted $50 \mathrm{~cm}$ next to master core M12. In the uppermost part of the sedimentary succession, they reveal evidence of mixing, so the estimated accumulation rate should be treated as a maximum rate. The downward decrease in the ${ }^{210} \mathrm{~Pb}_{\mathrm{ex}}$ profile revealed an apparent sediment accumulation rate for the last century of $0.046 \pm 0.031 \mathrm{~cm} / \mathrm{yr}$. The ${ }^{137} \mathrm{Cs}$ activity profile was characterized by maximum values in the near-surface sediments, decreasing with sediment depth and reaching near zero values at $4 \mathrm{~cm}$ depth. Such a ${ }^{137} \mathrm{Cs}$ profile often results from post-depositional remobilization of this isotope; however, in general, the ${ }^{137} \mathrm{Cs}$ penetration depth corresponds to the time related to the introduction of this isotope into the environment and consequently to ${ }^{210} \mathrm{~Pb}$-based accumulation rates.

\section{Discussion}

\section{Origin of sand layers}

There are multiple possible sources and depositional processes leading to sand layer formation within the lowland coastal succession. The sediment may come from the erosion of nearby dunes, beaches, older Pleistocene sands or offshore sediments. The depositional processes may include aeolian, fluvial, and beach processes and marine inundations (storm surge, tsunami, and sea-level rise). The obtained results on sand layer properties are compared with end-member sample characteristics and are discussed below to provide insight into sediment provenance and depositional processes.

Considering the geometry of the sand layers (adjacent to the coastline and thinning landward, Fig. 1), it is very likely that the sand was delivered from the coast and/or offshore in the landward direction. Considering the grain size distributions represented by the grain size statistics (Fig. 3a,b), there is a clear 
overlap of samples from beach and dune. They are also similar to some relatively fine-grained samples collected from the sandy layers. However, the sandy layers composed of coarse sand are clearly distinguishable. Some sandy layers, in terms of grain size, partly overlap with the wetland deposits. This overlap is likely associated with very thin interlayering of both types of sediments and mixing of material. Moreover, thin sandy deposits may be completely incorporated and efficiently mixed with wetland/new soil deposits, so macroscopic recognition is not possible $(32,33)$. Thus, the comparison of grain size in sand layers with beach and dune sediments suggests that they could contribute to the pool of sediment sources. The presence of an additional sediment source is suggested by statistical analysis of the geochemical composition (Fig. 3c). The latter clearly shows that sand layers and wetland deposits are slightly different and are easily distinguishable from modern beach and dune deposits (Fig. 3). The heavy mineral assemblage of sand layers, although similar to coastal deposits, also revealed contributions from alternative sources.

Commonly used marine origin indicators are of limited significance because the Baltic Sea has very lowsalinity, brackish water. Nevertheless, the core sections with sand layers have slightly higher concentrations of salinity indicators such as $\mathrm{Na}$ and $\mathrm{K}$, both in sandy and intercalated wetland deposits, as marine waters are expected not only to be kept within sand layers but also to percolate through wetland sediments (34) (Fig. 3c)

The combined evidence from grain size, geochemistry (Fig. 2,3) and heavy minerals (Supplementary Table 6) indicates that sand layers are allochtonous deposits sourced from mixed beach, dune and an additional source - possible offshore sediments, and were likely transported by brackish water. Insights into the depositional processes forming the sand layers are given by macroscopic sedimentological and micromorphological analyses. Erosional lower contacts with scouring features and rip-up clasts of underlying wetland sediments identified close to the lower boundaries of sand units are typical characteristics of fast flow flooding events $(17,35)$ (Supplementary Fig. 1). Considering possible sediment sources and sedimentological properties, the aeolian and riverine origin of the sand layers may be excluded, and it is most likely that they were formed by storm surges or tsunamis. The tsunami origin of sandy deposits at the southern Baltic sea coast was hypothesized earlier by Piotrowski et al. (17). However, the sedimentary evidence of coastal flooding and geological evolution of the research area does not invoke the possibility of tsunami occurrence (11). The main characteristic which allows to differentiate between storm and tsunami deposits is the extent of the sand layers associated with the event. In the case of tsunami deposits the clay, sand and silt creates few tens of centimeters thick sand layers which extend up to few kilometers inland. Storm induced layers are of significantly smaller lateral extent, only up to few hundreds of meters. Thickness of sand layers associated with storms is from few tens of millimeters to few tens of centimeters.

\section{The history of storm surge flooding}

Here, we present the longest sedimentary record of storm surge flooding for the Baltic Sea to date; deposits of the last $7.5 \mathrm{ka} \mathrm{BP}$ include record of coastal flooding within two periods: from approximately 3.6 to $2.9 \mathrm{ka}$ BP and from approximately $0.7 \mathrm{ka}$ BP until present. It is likely that at $3.6 \mathrm{ka}$ BP, significant 
storm event(s) took place, which caused significant erosion of up to $70 \mathrm{~cm}$ of wetland sediments, assuming that previous land surface aggradation followed sea level rise (Fig. 4). The subsequent period between $3.6 \mathrm{ka}$ BP and $2.9 \mathrm{ka}$ BP represents the first well-preserved high-resolution record characterized by at least 15 major storm surge flooding events, represented by sand layers that are a few centimeters thick. The recurrence time of the events was approximately 46 years, and the frequency was approximately 2.1 per century. The storm layers are distributed evenly throughout this core section. Approximately $3.6 \mathrm{ka} \mathrm{BP}$, the sea was $1.5 \mathrm{~m}$ lower than today, and, assuming the nearshore bathymetry was similar to the current bathymetry, it is likely that the sea shore was approximately $200 \mathrm{~m}$ offshore of the modern shoreline (36). Thus, the preserved storm layers indicate a minimum landward inundation distance of approximately $360 \mathrm{~m}$.

The period between 2.9 and $0.7 \mathrm{ka}$ BP was characterized by very low accumulation rates in the range of $0.02 \mathrm{~cm} /$ year, likely caused by the low water table corresponding to regional droughts $(37,38)$, which limited the vertical aggradation of wetland sediments (Fig. 4). The study site was also likely protected by the developed coastal barrier (dune, beach ridge). From 0.7 ka BP onwards, the accumulation rate significantly increased to reach approximately $0.21 \mathrm{~cm} /$ year and represents the second period with a high-resolution sedimentary archive of storm surge flooding, beginning with the period of wetland aggradation at the site located at approximately $0.5 \mathrm{~m} \mathrm{bmsl}$. Although the surface of the wetland was below sea level, it was rarely inundated. Thus, the wetland was likely protected by well-developed coastal barriers, i.e., beach ridge, (fore)dunes. The sedimentary record for this time window includes 9 storm layers, which are thinner than those during the previous period (3.6-2.9 ka BP). The recurrence time of the events was approximately 77 years, and the frequency was approximately 1.3 per century. However, the storm surge layers are not distributed evenly, and most of the layers are concentrated in the uppermost part of the core section, representing the period from approximately 1750-1900 AD. The frequency of storm surge flooding for this period alone was 4.2 per century. If we assume the stable position of the sea shore at that time, close to the current position, then the minimum inundation distance based on the extent of the sand layers within transect B was up to $320 \mathrm{~m}$ inland.

\section{Major controls on storm surge flooding}

A high-resolution sedimentary archive from Mechelinki provides an opportunity to compare factors potentially controlling extreme storm surge flooding, including sea-level change and the development of coastal landforms within the two periods, each of them spanning approximately 700 years.

Between 3.6 and $2.9 \mathrm{ka} \mathrm{BP}$, the climate was approximately $0.2^{\circ} \mathrm{C}$ warmer than the Holocene average and slightly decreasing throughout the time period (39) (Fig. 5). The timing of enhanced storminess between 3.5 and 3.05 ka cal. yrs BP depicted from Mechelinki sedimentary archive fits into the broad scheme of Holocene Storm Periods for NW Europe based on Seine estuary sedimentary archive and Mont-SaintMichel Bay in northern France (40). There enhanced storminess is postulated for the period of 3.3 to 2.7 ka cal. yrs BP. Similarly it remains in agreement with the changing enhanced zonal North Atlantic storminess reconstruction from wind-transported material from Fils $\varnothing$ coastal wetland in western Denmark 
(41), where enhanced storminess was suggested to occur between 3.3 and 2.4 ka cal. yrs BP. During this period, at Mechelinki storm surge flooding occurred during steadily rising sea levels at a moderate rate. The storm flooding frequency recorded and archived in sediments was constant over the whole timespan. Our record lies in a period with weakly positive NAO oscillation pattern, but including some extended periods of strong negative NAO states (69) (Fig. 5).

During the second period of $0.7 \mathrm{ka} \mathrm{BP}$ until the present, the climatic conditions were more variable than during the first: the initial cooling was intensified during LIA and then followed by recent warming (4244) (Fig. 5). Before the LIA between 950 and 1300 AD the NAO had tendency to remain in a positive phase, while from 1400 to 1800 during LIA negative phases occurred more frequently (20) and turned again to more positive phases form $1850 \operatorname{AD}$ onward $(36,45)$. Similarly, the sea-level change trends were variable: initial steady rise, followed by a stabilization or even slight drop and the most recent increase. The storm surge flooding frequency varied throughout this period, and inundations were the most frequent during the particularly during the LIA termination, when the NAO remained mostly in positive mode and when the sea level was almost stable.

The studied site is located in an area with gentle inclination of the near-shore area. From comparison of the available reconstructions of sea level (26) and the presented bathymetric data (36), it was found that during the older period (3.6-2.9 ka BP), the shoreline was approximately $200 \mathrm{~m}$ offshore of the modern one. The subsurface of the Puck Lagoon consists of peat, which was left after wetland successively flooded along with the rising sea-level. The coastal wetland, located more inland, kept pace with the sealevel rise, however, it was at a constant pressure from the transgressive sea; it was exposed to storminduced coastal flooding (Fig. 4). At that time the storm flooding events reached far inland (up to $160 \mathrm{~m}$ from the present-day shoreline, what was about $360 \mathrm{~m}$ from the shoreline $3 \mathrm{ka} \mathrm{BP,} \mathrm{Fig.} \mathrm{1).} \mathrm{The} \mathrm{relatively}$ thick storm layers indicate the coastal landforms protection against flooding, present at that time, did not reach critical dimensions for full protection (46) and the peatland was continuously being flooded. It may be concluded that at this early period, when the coastal wetland was under constant pressure of transgressing sea, the morphology of the coast was less well developed and storms had more impact on the coast. At approximately $2.9 \mathrm{ka}$ BP the frequency of flooding dropped and the protection of the lowland was likely assured by coastal barriers which by this time had reached critical dimensions.

From the analysis of the sea-level data it is clear that during the second period ( $0.7 \mathrm{ka}$ BP to present time), initially, the surface of the wetland was below sea level. However, although the area was susceptible to flooding, it was not inundated by the sea; therefore, protecting barriers in the form of beaches, beach ridges and initial dunes still have existed. Only the most severe storm surge events were able to flood the area. The protection was sufficient to defend against storm surge flooding until the transition to LIA. However, even then the storms left more frequent, thinner and less extensive sand layers than during the older studied period.

Our study indicates that archived evidence of intense storminess is simultaneous with enhanced storminess episodes identified elsewhere in the North Atlantic region (40). These storminess periods are 
associated with shifting circulation patterns (especially NAO) and the climate-change related shift in the position of storm tracks (47). Despite the fact that both time spans represent periods of enhanced storminess recognized in northwestern Europe (40) and the rising or fluctuating sea-level, the coastal morphology was different as well as the sedimentary record of storm flooding. Therefore we claim that the stage of evolution of coastal landforms is superior to sea-level and climatic trends in controlling the susceptibility of the coast to extreme storm surge flooding.

\section{Conclusion}

Our results prove that sedimentary archives of storm surge coastal flooding may be useful not only in deciphering the history and frequency of these events but also offer an opportunity to provide insights into the factors controlling their magnitude. Our study site at Mechelinki there was a unique opportunity to compare sedimentary record of the storminess throughout two periods of variable sea-level trends and climatic conditions.

Our results show that periods of climatically driven high-frequency storm flooding took place during various sea-level change trends, but the susceptibility of the area to flooding was mainly dependent on the development of coastal landforms, and less dependent on the phase of the sea-level change. Sandy barriers may protect the coasts against flooding although being subjected to constant pressure from the rising sea-level and storm surges.

The studied Puck Bay coast is a representative example of sandy coasts, which comprise $30 \%$ of the global shoreline. Our results may be considered to provide an outlook for the fate of the sandy coasts in the future, in conditions of the rising sea-level and enhanced storminess. Playing an important role in defending lowland coasts against storm surge flooding, coastal barriers should be protected and preserved. Their destruction due to natural processes or human action may lead to more frequent and severe flooding of the lowland coasts.

\section{Methods}

\section{Fieldwork}

Initially, 15 Russian sampler cores were extracted along four transects in the north, middle and south of the research area. The exact location of the cores was determined by GPS, and their height was read from lidar data. Soil sampler cores were described in the field. Master core M12 was taken using a Cobra TT mechanical drill. The compaction rate within core M12 was calculated based on the penetration depth compiled with the length of the core. Compaction varies with depth, depending on the nature of the deposit, and within the peat itself, depending on the degree of decomposition of the peat and the admixture of mineral matter. Compaction ranged from 4 to $13 \mathrm{~cm}$ for each $1 \mathrm{~m}$ long core section. Master core M12 was described in detail and sampled for further analyses. Laboratory analyses were also performed on 6 end member samples taken from the beach (3 samples) and dune (3 samples). 


\section{Geochronology}

The chronology of master core M12 and its twin core was based on combined accelerated mass spectrometry (AMS) ${ }^{14} \mathrm{C}$ and gamma spectrometry ${ }^{210} \mathrm{~Pb}$ and ${ }^{137} \mathrm{Cs}$ dating. Fourteen bulk peat samples and a single wood sample were selected for radiocarbon dating to provide a general core chronology and to date particular event layers. In the latter case, the samples were collected from below and above selected sandy layers. The samples were measured in the Poznań Radiocarbon Laboratory (Poland), Beta Analytics Laboratory (USA) and GADAM Centre (Gliwice, Poland). Radiocarbon ages were calibrated with CALIB Rev. 8.1.0 (48) using the IntCal20 calibration dataset (49). The youngest sediments (upper $12 \mathrm{~cm}$ ) were analyzed for short-lived radionuclides ${ }^{210} \mathrm{~Pb}$ and ${ }^{137} \mathrm{Cs}$ using a Canberra BE3830 gamma spectrometer at the Institute of Geology, Adam Mickiewicz University in Poznań, Poland. The sediment accumulation rate was calculated by applying a constant flux sedimentation rate model using the serac package (50).

The combined age-depth model for core M12 was constructed using the available results and applying the Bacon software package (51). The sandy event layers were treated as instantaneous deposits, and the 4 ages were not considered, as they provided significantly older ages than samples taken from sediments below them.

\section{Physical core description, loss-on-ignition and grain-size analyses}

Master core M12 was photographed and described in the laboratory in terms of physical appearance, namely, sediment type, texture, color, and the type of boundary between identified sediment types. The loss-on-ignition technique, performed on 185 samples, was used to establish the percentage amount of organic versus mineral matter within the deposits (52).

Sediment grain size from 60 samples from core M12 and 8 end member samples were established using a Morphology G3 optical automated microscope at the Faculty of Geographical and Geological Sciences, Adam Mickiewicz University in Poznań, Poland. Prior to analysis, the samples were burned in a muffle furnace at $550^{\circ} \mathrm{C}$ for 3 hours to remove organic material. As the amount of siliciclastic material smaller than $63 \mu \mathrm{m}$ was negligible prior to the analysis on Morphology G3, samples were wet sieved on a $63 \mu \mathrm{m}$ sieve. The grain-size distribution was plotted with Gradistat 8.0, using the logarithmic method of moments (53).

\section{Micromorphology}

Selected sections of master core M12 (8 thin sections), comprising sandy layers, were subjected to micromorphological analysis. The deposits extracted from the coring tube were dried and impregnated using epoxy resin. After impregnation, the samples were cut into 8 thin sections. Slides were scanned on a high-resolution scanner to produce images of all samples and analyzed under an optical/petrographic microscope under plane light conditions. The description protocol followed Leszczyńska et al. (54) and 
the terminology developed by pedologists (55). Particular attention was given to depositional and erosional structures typical for flood deposits (56).

\section{Geochemistry}

A handheld X-ray Tracer III ED-XRF (Bruker AXS, USA) spectrometer was used to assess the concentrations of 9 selected major and 7 selected trace elements in 109 samples from master core M12 and 6 end member samples. The spectrometer was operated in the quantitative mode described by the manufacturer. Two calibration standards were used: Bruker Mudrock Major for analysis of $\mathrm{Ca}, \mathrm{Ti}, \mathrm{S}, \mathrm{Si}$, $\mathrm{Na}, \mathrm{K}, \mathrm{Cr}, \mathrm{Zn}$ and $\mathrm{Mg}$ and Bruker Mudrock Trace for determination of $\mathrm{Mn}, \mathrm{Sr}, \mathrm{Fe}, \mathrm{Zr}, \mathrm{Rb}, \mathrm{Ni}$, and $\mathrm{As}$ as described by Kozak et al. (57).

\section{Diatom analysis}

Micropaleontological analysis for the presence/absence and the type of diatoms was conducted for selected sandy event layers on 9 samples; in one case, the organic deposits below and above the minerogenic layer were also analyzed. Preparation of collected material for diatom analysis was conducted according to standard procedures. Diatom valves were identified to the lowest possible taxonomic level with reference to (58).

\section{Heavy minerals analysis}

The heavy minerals were analyzed from 4 samples from the sand layers within master core M12 and 2 end member samples (from the beach and from the dune). Samples were dried and sieved, and minerals from fractions of $125-250 \mu \mathrm{m}$ were separated using sodium polytungstate liquid of density $<2.85 \mathrm{~g} / \mathrm{cm}^{3}$. Microscopic slides were prepared using Canada Balsam and analyzed under a petrographic microscope with cross-polarized optics.

\section{Statistical analysis}

Factor analysis was undertaken on 29 samples from core M12 and 6 end member samples ( 3 beach and 3 dune samples). The calculations were made in $\mathrm{R}$ software (59)using 2 factors: Bartlett's score and rotation varimax and autoplot function. The aim was to establish the similarities between the discrete samples.

\section{Declarations}

\section{Acknowledgments}

We'd like to thank the following people for their assistance: Bartosz Plóciennik and staff of the Seaside Landscape Park, Regional Director of the Environmental Protection Office and its staff, Marine Institute in Gdańsk, Tomasz Goslar, Jakub Niebieszczański, Krzysztof Pleskot, Piotr Majorek, Sebastian Teka, Michał 
Jankowiak, Angelika Gapa, Mikołaj Kodzis and Szymon Świątek. We are grateful to Anonymous Reviewers of the previous version of the paper, which helped to improve it.

\section{Funding}

The research was supported by National Science Centre (Poland) grant OPUS nr 2018/29/B/ST10/00042 (KS).

\section{Author contributions}

Conceptualization: KL, KS, WS

Methodology: KL, KS, WS

Investigation - field- and desk-based, physical description of the cores: KL, KS

Research techniques - heavy minerals: RJ

Research techniques - geochemistry: KL, PN

Research techniques - diatom analysis: MK

Research techniques - micromorphology: KL

Research techniques - Pb/Cs dating, age model: WS

Statistical analysis: $\mathrm{KL}$

Visualization: KL, DM

Supervision: KS, WS

Writing - original draft: $\mathrm{KL}$

Writing - review \& editing: KL, KS, WS, DM

\section{Competing interests}

The authors declare that they have no competing interests

\section{References}

1. Luijendijk, A., Rahasinghe, R., Baart, F., Donchyst, G. \& Aarninkohf, S. The state of the World's beaches. Scient. Rep. 8, 6641 (2018)

2. Clarke, M. L. \& Rendell, H. M. The impact of North Atlantic storminess on western European coasts: A review. Quat. Int. 195, 31-41 (2009) 
3. Shukla, J. S. P et al. Climate Change and Land: an IPCC special report on climate change, desertification, land degradation, sustainable land management, food security, and greenhouse gas fluxes in terrestrial ecosystems (in press)

4. Hallegate, S., Green, C., Nicholls, R. J. \& Corfee-Morlot, J. Future flood losses in major coastal cities. Nat. 3, 802-806 (2013)

5. Kirezci, E. et al. Projections of global-scale extreme sea levels and resulting episodic coastal flooding over the 21st Century. Scient. Rep. 10, 11629 (2020)

6. Vousdoukas, M. I. et al., Sandy coastlines under threat of erosion. Nat. Clim. Change 10, 260-263 (2020)

7. Cooper, J. A. G. et al., Sandy beaches can survive sea-level rise. Nat. Clim. Change 10, 993-995 (2021)

8. Fruergaard, M., Andersen, T. J., Johannessen, P. N., Nielsen \& L. H., Pejrup, M. Major coastal impact induced by a 1000-year storm event. Scient. Rep. 3, 1051 (2013)

9. Goslin, J. \& Clemmensen, L. B. Proxy records of Holocene storm events in coastal barrier systems: Storm-wave induced markers. Quat. Sci. Rev. 174, 80-119 (2017)

10. Engelhart, S. E., Pilarczyk, J. E., \& Rovere, A. Storms and extreme events: insights from the historica and palaeo record. Pages Mag. 27, 26-27 (2019)

11. Moskalewicz, D., Szczuciński, W., Mroczek, P. \& Vaikutienè, G. Sedimentary record of historical extreme storm surges on the Gulf of Gdańsk coast, Baltic Sea. Mar. Geol. 420, 1-15 (2020)

12. Hodge, J. B., Anzah, F., Dixon, R. W. \& Hayes, M. O. Hurricanes as geological agents: case studies of hurrcanes Carli, 1961 and Cindy, 1963. Progr. in Phys. Geogr.: Earth and Env. 42, 257-264 (2018)

13. M. M. Ball, E. A. Shinn, K. W. Stockman, The geologic effects of hurricane Donna in South Florida. The J. of Geol. 75, 583-597 (1967)

14. B. Van Vliet Lanoe et al., Middle- to Late-Holocene storminess in Brittany (NW France): part II - the chronology of events and climate forcing. The Hol. 24, 434-453 (2014)

15. F. Oliva, A. Viau, M. Peros, M. Bouchard, Paleotempestology database for the western North Atlantic basin. The Hol. 28, 1664-1671 (2018)

16. P. Pouzet et al., Chronology of Holocene storm events along the European Atlantic coast. Progr. in Phys. Geogr.: Earth and Env. 42, 431-450 (2018)

17. Piotrowski, A. et al., Sedimentary evidence of extreme storm surge or tsunami events in the southern Baltic Sea (Rogowo area, NW Poland). Geol. Quart. 61, 973-986 (2017)

18. Kowalczyk, K. Changes in mean sea level on the polish coast of the Baltic sea base on tide gauge data from the years 1811-2015. Acta Geodyn. et Geomat. 16, 195-209 (2019)

19. Hünicke, B. et al., in Second assessment of climate change for the Baltic Sea basin, regional climate studies, (ed. The BACC II Team) 155-188 (2015)

20. Börgel, F., Frauen, C., Neumann, T., S. Schimanke, \& Meier, H. E. M. Impact of the Atlantic Multidecadal Oscillation on Baltic Sea Variability. Geophys. Res. Let. 45, 9880-9888 (2018) 
21. Almar, R. et al. A global analysis of extreme coastal water levels with implications for potential coastal overtopping. Nat. Com. 12, 3775 (2021)

22. Mojski, J. E. Objaśnienia do mapy geologicznej Polski 1:200 000, arkusz Gdańsk. (Państwowy Instytut Geologiczny Warszawa, 1979)

23. Garetsky, R. G. et al., The neogeodynamic state of the Baltic sea depression and adjacent areas some conclusion from the IGCP-Project 346: Neogeodyn. Balt. Brandenburgische Geowiss. Beitr. 8, 43-47 (2001)

24. S. Uścinowicz, A relative sea-level curve for the Polish Southern baltic Sea. Quat. Int. 145-146, 86105 (2006)

25. Uścinowicz, S. et al., Climate and sea level variability on a centennial time scale over the last 1500 years as inferred from the Coastal Peatland of Puck Lagoon (southern Baltic Sea). The Hol. 30, 1801-1816 (2020)

26. Lampe, R. \& Lampe, M. The role of sea-level changes in the evolution of coastal barriers - an example from the southwestern Baltic Sea. The Ho/ 31, 515-528 (2021)

27. Nowacki, J. in Zatoka Pucka (ed. Korzeniewski, K.) 79-111 (Instytut Oceanografii Uniwersytetu Gdańskiego, Gdańsk, 1993)

28. Przygrodzki, P. \& Letkiewicz, B. Charakterystyka wezbrań sztormowych wzdłuż polskiego wybrzeża Morza Bałtyckiego. Inż. Morska i Geotechn. 3, 158-166 (2015).

29. Wolski, T. et al., Extreme sea levels at selected stations on the Baltic Sea coast. Oceanologia 56, 259-290 (2014).

30. Jarosz, E. \& Kowalewski, M. in Zatoka Pucka (ed. Korzeniewski, K.) 147-159 (Instytut Oceanografii Uniwersytetu Gdańskiego, Gdańsk, 1993)

31. Qian, B. \& Saunders, M. A. Seasonal predictability of wintertime storminess over the North Atlantic. Geophys. Res. Let. 30, 1698 (2003).

32. Szczuciński, W. in Geological Records of Tsunamis and Other Extreme Waves (eds. Engel, M., Pilarczyk, J., May, S. M., Brill, D. \& Garrett, E.) 443-469 (Elsevier, Rotterdam, 2020)

33. Spiske, M., Tang, H. \& Bahlburg, H. Post-depositional alteration of onshore tsunami deposits Implications for the reconstruction of past events. Earth-Sci. Rev. 202, 103068 (2020)

34. Chagué-Goff, C., Szczuciński, W. \& Shinozaki, T. Applications of geochemistry in tsunami research: A review. Earth-Sci. Rev. 165, 203-244 (2017)

35. Goff, J., Chagué-Goff, C., Nichol, S., Jaffe, B. \& Dominey-Howes, D. Progress in palaeotsunami research. Sed. Geol. 243-244, 70-88 (2012)

36. Polish Geological Institute National Research Institute: https://www.pgi.gov.pl/gdansk/geologiamorza-i-wybrzeza/opracowania/6393-mapa-geologiczna-dna-baltyku.html (2021)

37. Pleskot, K., Tjalingii, R., Makohonienko, M., Nowaczyk, N. \& Szczuciński, W. Holocene palaeoecological reconstruction of Lake Strzeszyńskie (western Poland) and its implications for the Central European climatic transition zone. J. of Palaeolimn. 59, 443-459 (2018) 
38. Lamentowicz, M. et al., Reconstructing climate change and ombrotrophic bog development during the last 4000years in northern Poland using biotic proxies, stable isotopes and trait-based approach. Palaeogeogr., Palaeoclim., Palaeoecol. 418, 261-277 (2015)

39. Marcott, S. A., Shakun, J. D., Clark, P. U. \& Mix, A. C. A reconstruction of regional and global temperature for the past 11300 years. Science 339, 1189-1201 (2013)

40. Sorrel, P. et al., Persistent non-solar forcing of Holocene storm dynamics in coastal sedimentary archives. Nat. Geos. 5, 892-896 (2012)

41. Goslin, J. et al. Holocene centennial to milennial shifts in North-Atlanti storminess and ocean dynamics. Scient. Rep. 8, 12778 (2018)

42. Olsen, J., Anderson, N. J. \& Knudsen, M. F. Variability of the North Atlantic Oscillation over the past 5,200 years. Nat. Geos. 5, 808-812 (2012)

43. Kopp, R. E. et al., Temperature-driven global sea-level variability in the Common Era. Proc. of the Nat. Acad. of Sci. 113, 1434-1441 (2016)

44. Mann, M. E. et al., Global signatures and dynamical origins of the Little Ice Age and Medieval Climatic Anomaly. Sci. 326, 1256-1260 (2009)

45. Landrum, L. et al., Last millennium climate and its variability in CCSM4. J. of Clim. 26, 1085-1111 (2013).

46. van Heteren, S. in Coastal Environments and Global Change, (ed. Masselink, G. \& Gehrels, R.) 194226 (Wiley, Chichester, 2014)

47. Folland, C. K. et al., The summer North Atlantic Oscillation: past, present and future. J. of Clim. 22, 1082-1103 (2009)

48. Stuiver, M. \& Reimer, P. J. Extended 14C data based and revised CALIB 3.0 14C age calibration program. Radiocarb. 35, 215-230 (1993)

49. Reimer, P. J. et al., The IntCal2 Northern Hemisphere Radiocarbon Age Calibration Curve (0-55 cal kBP). Radiocarb. 62, 725-757 (2020)

50. Bruel, R. \& Sabatier, P.serac: an R package for ShortlivEd RAdionuclide chronology of recent sediment cores. J. of Env. Radioact. 225, 106449 (2020)

51. Blaauw, M. \& Christen, J. Flexible paleoclimate age-depth models using an autoregressive gamma process. Bay. Anal. 6, 457-474 (2011)

52. Plater, A. J., Kirby, J. R., Boyle, J. F., Shaw, T. \& Mills, H. in Handbook of sea-level research, (eds. Shennan, I., Long, A. J. \& Horton, B. P.) 313-318 (Wiley, Chichester, 2015)

53. Blott, S. J. \& Pye, K. GRADISTAT: a grain size distribution and statistics package for the analysis of unconsolidated sediments. Earth Surf. Proc. and Landf. 26, 1237-1248 (2001).

54. Leszczynska, K., Boreham, J. \& Boreham, S. A Novel Methodological Approach for Thin-Section Description and its Application to periglacially disturbed Pleistocene deposits from Danbury, Essex, UK. Neth. J. of Geos. 90, 271-291 (2011) 
55. Stoops, G. Guidelines for analysis and description of soil and regolith thin sections. (Soil Science Society of America, Madison, Wisconsin, USA, 2003)

56. Morton, R. A., Gelfenbaum, G. \& Jaffe, B. E. Physical criteria for distinguishing sandy tsunami and storm deposits using modern examples. Sed. Geol. 200, 184-207 (2007).

57. Kozak, L. et al., Handheld ED-XRF spectrometers in geochemical investigation: comparative studies for glacial deposits from Spitsbergen. Polish Pol. Res. 42, 163-172 (2021)

58. Krammer, K. \& Lange-Bertalot, H. in Pascher's Suuswasserflora von Mitteleuropa (ed. Ettl, H.) vol. 1-4 (Gustav Fischer Verlag, Stuttart, 1991)

59. R-project: https://www.r-project.org/

\section{Figures}

\section{Figure 1}

Location of the research area. A. Mechelinki research area at the southern Baltic Sea coast (Poland), Puck Bay within the Gulf of Gdańsk. B. Orthophoto map of the Mechelinki area with locations of coring sites and geological cross-sections. C. Geological cross-sections through the depositional succession at Mechelinki, with sandy event layers and wetland deposits. D. Close-up of recent wash-over fans (landward limit marked with dotted line). 


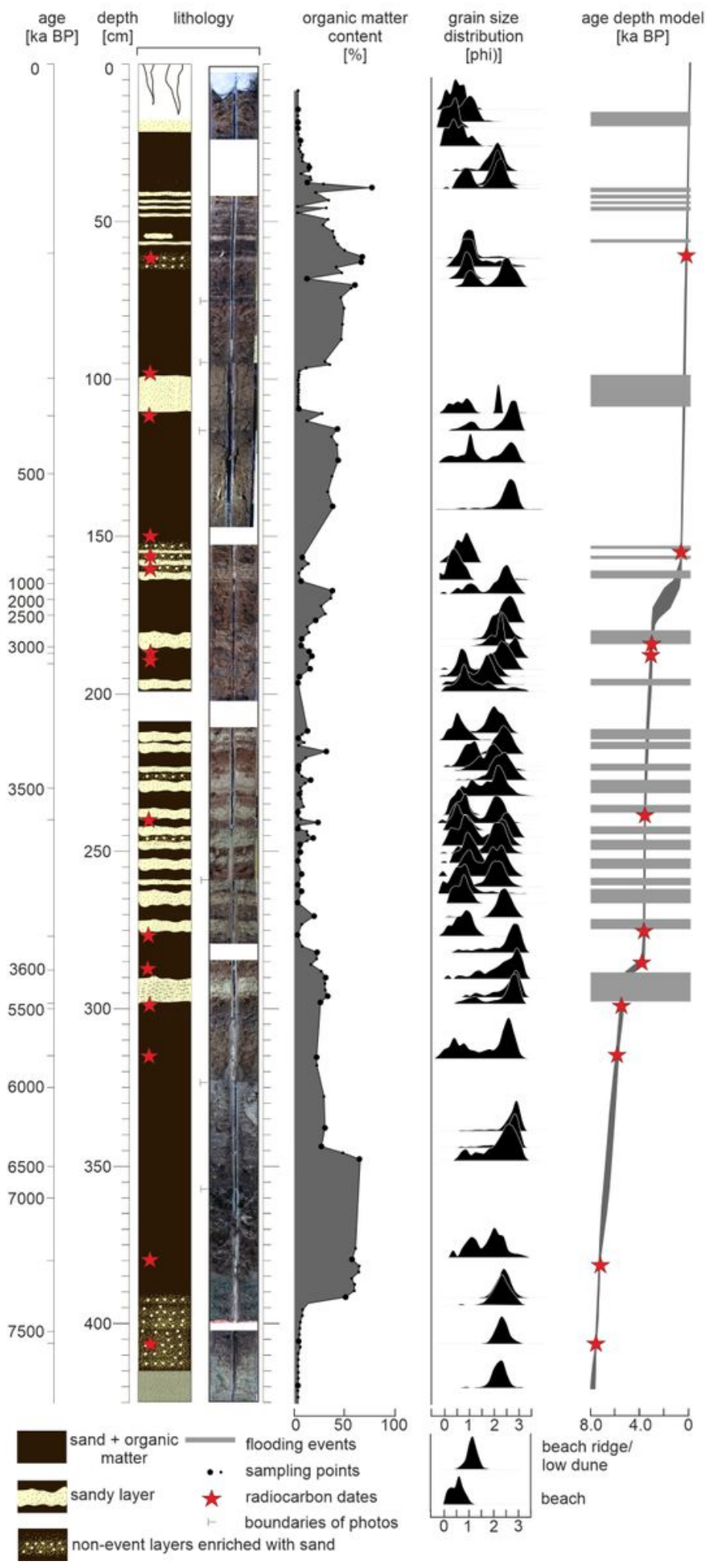

Figure 2

Master core M12. The core log, photography of the core, percentage of organic matter content, grain size distributions and age depth model. See Fig. 1B for location of master core M12. 

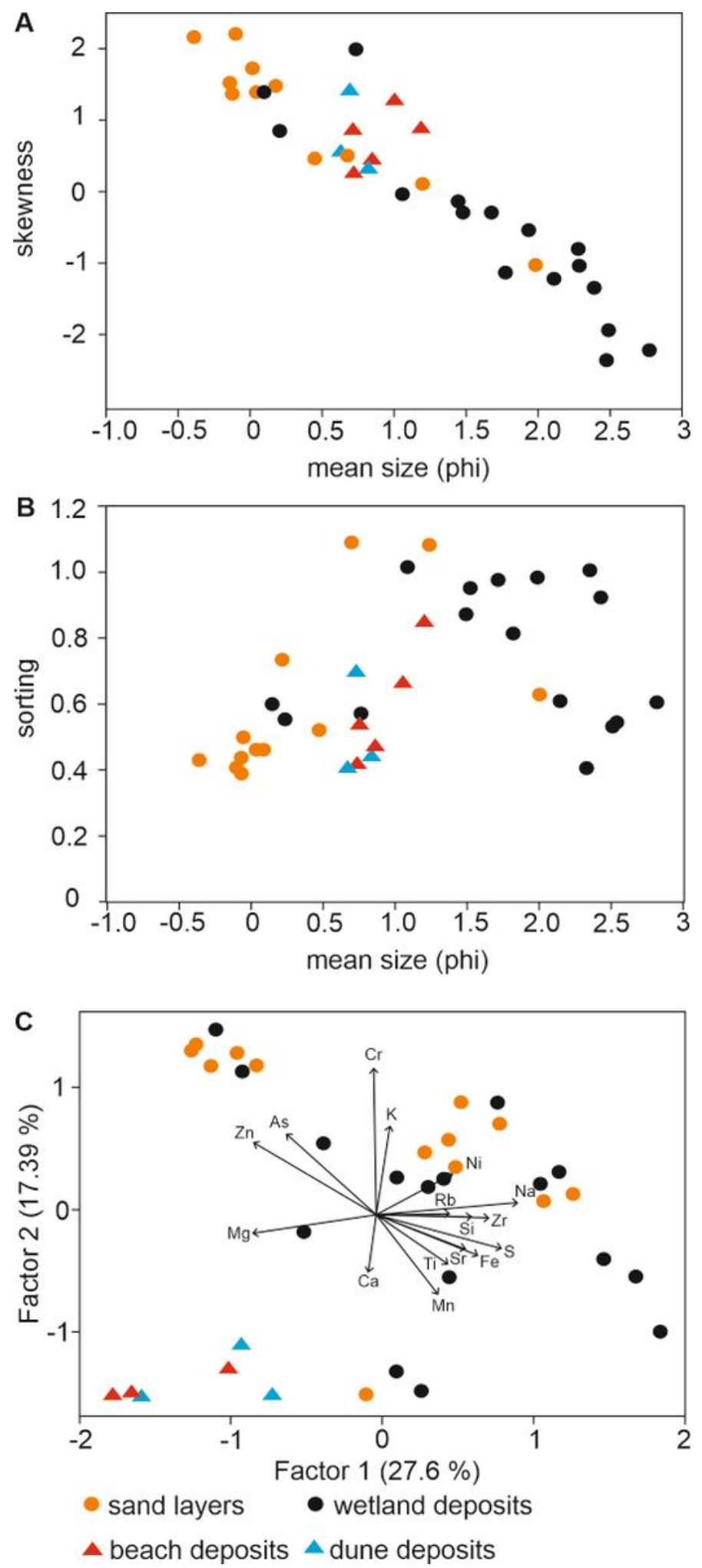

Figure 3

Grain-size and geochemical data. Samples were taken from event and non-event layers within master core M12 from Mechelinki and modern beach and dune deposits. A. Mean grain-size (in phi units) vs. skewness. B. Mean grain-size (in phi units) vs. sorting. C. Factor analysis of the geochemical data. The arrows accompanied by element symbols indicate the eigenvector values in the biplot. 


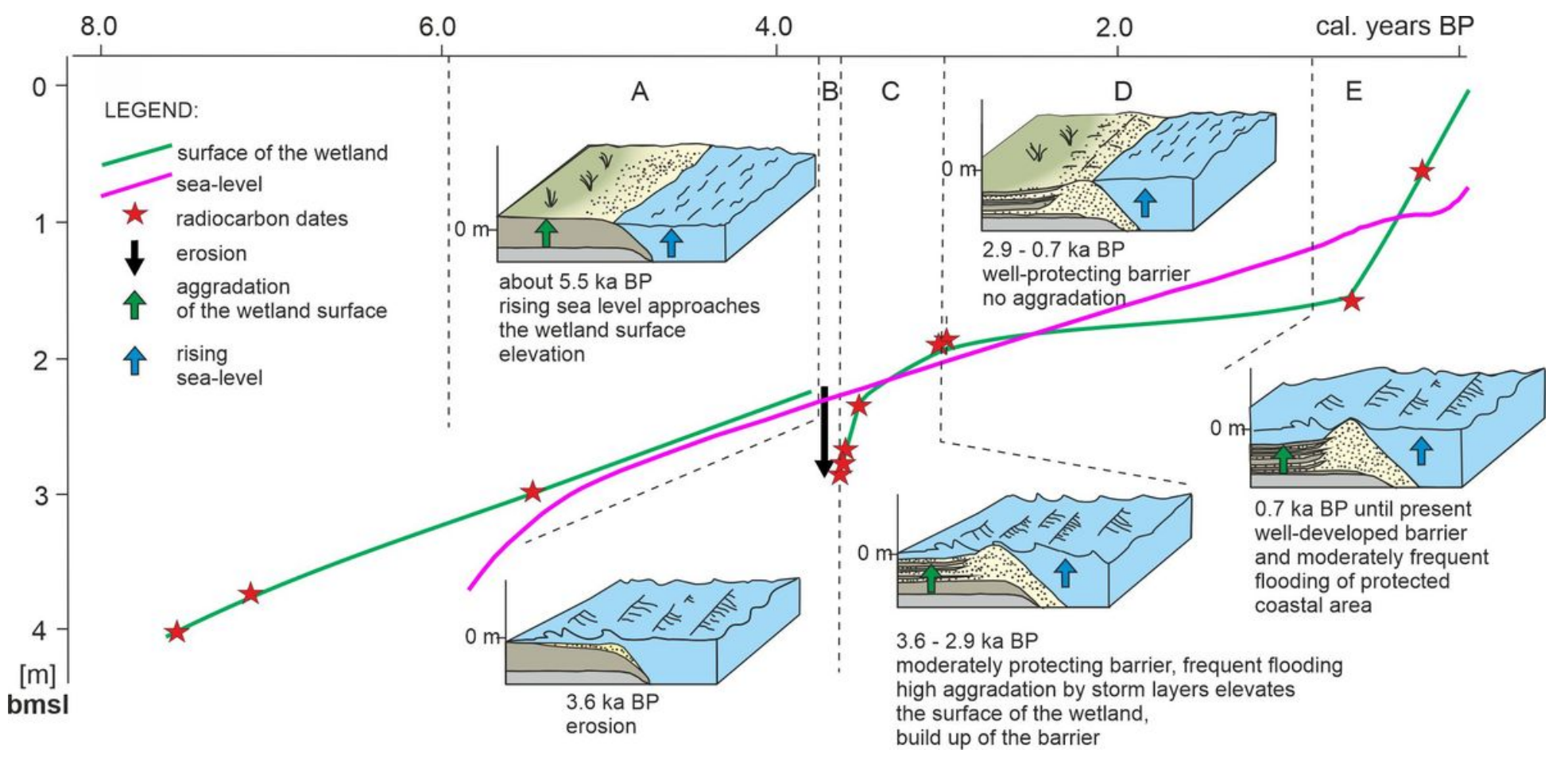

Figure 4

Sea level and coastal landform development reconstruction. Sections A to E depict discrete time spans represented schematically within the block-diagrams. 

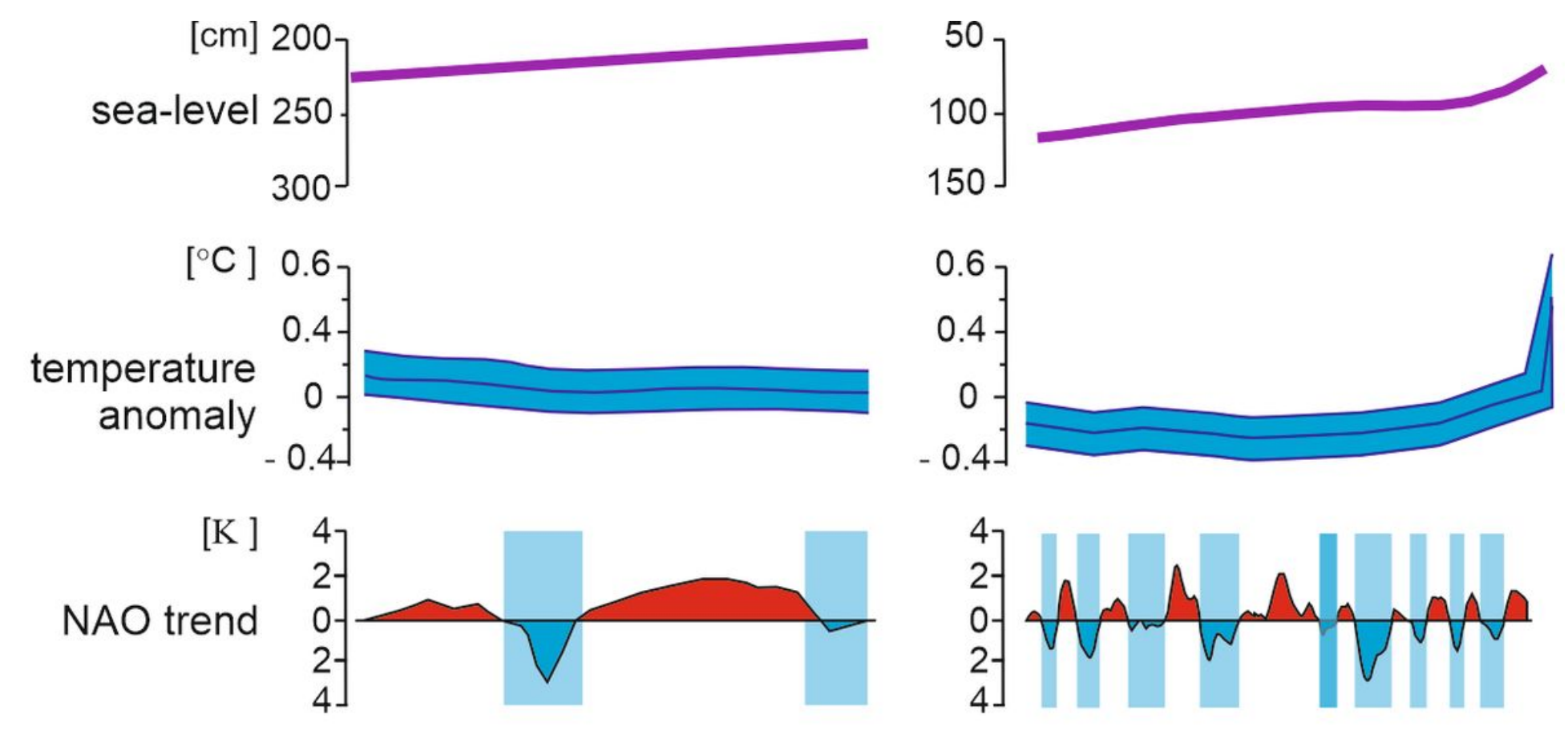

Holocene storm periods
^им r.......
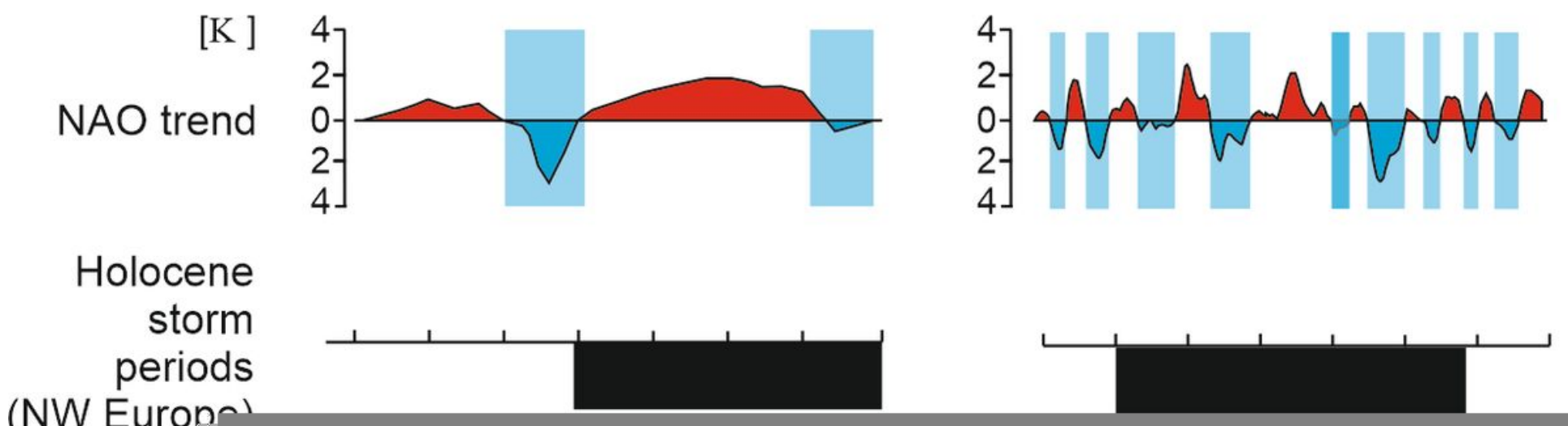

Figure 5

Comparison of the extreme storm surge flooding controlling factors within the two studied time periods. Data sources: sea-level (based on $(18,24,25)$ ), temperature anomaly based on (39), NAO trend 3.6-2.9 ka BP based on (42) and $0.7 \mathrm{ka} \mathrm{BP}$ until present based on (45), Holocene storm periods based on (40).

\section{Supplementary Files}

This is a list of supplementary files associated with this preprint. Click to download.

- TOBESUBMITTEDSupplementarymaterialsLeszczynskaetal.pdf 